\title{
Perkawinan sesama Jenis dan Hak Asasi Manusia : Penerapan Prinsip Equality dalam Putusan Obergefell, et.al. v. Hodges, USA serta Analisis mengenai Perkawinan Sesama Jenis di Indonesia
}

\author{
Holy K.M. Kalangit \\ Heru Susetyo \\ Fakultas Hukum Universitas Indonesia \\ Email Korespondensi : hsusetyo@ui.ac.id
}

\begin{abstract}
The 'rights' and 'equality' arguments have been widely used in the last couple of years by the samesex marriage supporters in claiming the legalization of same-sex marriage. The principle of equality in same-sex marriage legalization claims is closely related with the concept of human rights on the ground that the principle of equality is considered as one of the most important principles in the said concept. The decision of the Supreme Court of the United States of America in Obergefell et al. v. Hodges, Director, Ohio Department of Health is the latest decision concerning the legalization of same-sex marriage that changes radically the legality of same-sex marriage in the United States and may affect other nations. This research analyzes the said Decision, specifically on the application of the principle of equality. This research also analyzes the same-sex marriage issue in Indonesia from the perspective of universality and cultural relativism of human rights. The conclusion of this research is that the principle of equality in the Decision of the Supreme Court of the United States of America was not correctly applied and therefore it cannot be used in the same-sex marriage claims. And in Indonesia, it can be concluded that from the perspective of universality and cultural relativism of human rights, same-sex marriage cannot be legalized.
\end{abstract}

Keywords : Human; Rights; same-sex; Marriage, Equality.

\begin{abstract}
ABSTRAK
Argumen mengenai 'hak' dan 'equality' banyak digunakan beberapa tahun belakangan ini dalam menuntut legalisasi perkawinan sesama jenis oleh para pendukungnya. Penerapan prinsip equality dalam tuntutan legalisasi perkawinan sesama jenis adalah berkaitan erat dengan konsep hak asasi manusia karena prinsip equality merupakan salah satu prinsip penting dalam konsep tersebut. Putusan Mahkamah Agung Amerika Serikat dalam kasus Obergefell et al. v. Hodges, Director, Ohio Department of Health merupakan putusan pengadilan yang terbaru mengenai perkawinan sesama jenis dan merupakan putusan penting yang mengubah secara radikal mengenai keabsahan perkawinan sesama jenis di Amerika Serikat dan mempunyai pengaruh besar ke Negara - Negara lain. Penelitian ini menganalisis putusan Mahkamah Agung Amerika Serikat tersebut, khususnya mengenai penerapan prinsip equality. Penelitian ini juga menganalisis mengenai perkawinan sesama jenis di Indonesia, apabila ditinjau dari perspektif universalitas dan relativisme budaya dalam hukum hak asasi manusia. Disimpulkan bahwa penerapan prinsip equality dalam Putusan Mahkamah Agung Amerika Serikat tersebut secara khusus dan dalam isu perkawinan sesama jenis secara umum adalah tidak tepat. Di Indonesia, dari perspektif universalitas - relativisme budaya hak asasi manusia maupun dari penerapan prinsip equality, disimpulkan bahwa perkawinan sesama jenis tidak dapat dilegalisasi.
\end{abstract}

Kata kunci : Hak; Asasi; Sesama Jenis; Perkawinan; Persamaan. 


\section{Pendahuluan}

Perkawinan sesama jenis saat ini telah dilegalisasi ${ }^{1}$ di lebih dari 20 (dua puluh) negara di dunia ${ }^{2}$. Namun penerapan prinsip equality pada putusan Obergefell, et.al. v. Hodges secara khusus maupun dalam isu perkawinan sesama jenis secara umum adalah tidak tepat, dan perkawinan sesama jenis bukan merupakan hak asasi manusia di Indonesia apabila ditinjau dari perspektif universalitas - relativisme budaya dari hak asasi manusia.

Permasalahan hak asasi manusia dalam konteks perkawinan, yaitu mengenai hak untuk menikah/right to marry merupakan sesuatu yang mengalami perkembangan. Hakim Kennedy dalam putusan Mahkamah Agung Amerika Serikat dalam kasus James Obergefell, et.al. v. Hodges, Director, Ohio Department of Health ${ }^{3}$ menyatakan bahwa Mahkamah Agung Amerika Serikat pernah membatalkan aturan larangan perkawinan antar rasial ${ }^{4}$, dan juga bahwa terpidana tetap memiliki hak untuk menikah ${ }^{5}$, dan pada saat ini, isu mengenai perkawinan masuk pada perdebatan mengenai apakah pasangan sesama jenis juga memiliki hak untuk melangsungkan perkawinan ataukah tidak. Beberapa tahun belakangan menurut Crehan dan Rickenbacker para pendukung perkawinan sesama jenis banyak memfokuskan pada argumen mengenai 'hak' dan 'equality'. 6

\footnotetext{
${ }^{1}$ Legalisasi dalam Penelitian ini merujuk pada pengertian: membuat menjadi sah secara hukum. Lih. Black's Law Dictionary di mana to legalize diartikan sebagai: "The act of legalizing or making legal or lawful." http://thelawdictionary.org/legalization/, diakses pada 29 Mei 2017.

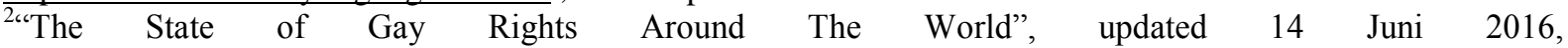
https://www.washingtonpost.com/graphics/world/gay-rights/, diakses pada 19 Mei 2017.

${ }^{3}$ Supreme Court of the United States, Obergefell et al. v. Hodges, Director, Ohio Department of Health, et.al, No. 14-556, 14-562, 14-571, 14-574, diputuskan pada 26 Juni 2015. Putusan diunduh dari https://www.supremecourt.gov/opinions/14pdf/14-556 3204.pdf, diakses pada 10 April 2016. Pemohon dalam kasus ini adalah 14 (empat belas) pasangan sesama jenis, dan dua orang pria yang pasangan sesama jenisnya telah meninggal dunia pada saat persidangan. James Obergefell merupakan salah satu dari para pemohon. Pihak termohon, Richard Hodges, adalah Direktur dari Departemen Kesehatan Ohio. Negara bagian Ohio, Michigan, Kentucky dan Tennessee mendefinisikan perkawinan sebagai persatuan antara seorang pria dan seorang wanita dan tidak mengakui perkawinan sesama jenis. Pemohon menggugat hukum di negara - negara bagian tersebut bahwa ketentuan tersebut bertentangan dengan Fourteenth Amendment dari Konstitusi Amerika Serikat, dengan memasukkan permohonan pada pengadilan negeri federal di negara bagian masing - masing. Para pemohon berargumen bahwa Fourteenth Amendment mengharuskan negara - negara bagian tersebut untuk melegalkan perkawinan sesama jenis dan mengakui keabsahan dari perkawinan sesama jenis tersebut yang dilakukan di yurisdiksi lain. Dalam masing - masing kasus, pengadilan negeri federal memenangkan permohonan para pemohon. Pada tingkat banding, Pengadilan Banding pada Sixth Circuit membalikkan putusan tersebut dan menyatakan bahwa larangan negara - negara bagian terhadap perkawinan sesama jenis dan penolakan untuk mengakui perkawinan sesama jenis yang dilakukan di negara bagian lain tidaklah melanggar hak - hak pasangan tersebut akan perlindungan setara dan due process menurut Fourteenth Amendment. Para pemohon kemudian membawa kasusnya pada Mahkamah Agung Amerika Serikat yang kemudian memenangkan pemohon.

${ }^{4}$ Loving v. Virgina 388 U.S. 1, diputuskan pada 12 Juni 1967.

${ }^{5}$ Turner v. Safley, 482 U.S. 78, diputuskan pada 1 Juni 1987.

${ }^{6}$ Margaret Gram Crehan dan Katherine Rickenbacker, "The Changing Debate on Same-Sex Marriage in the United States", Fall 2006-Spring 2007, http://quod.lib.umich.edu/cgi/t/text/textidx?cc=mfsfront;c=mfs;c=mfsfront;idno=ark5583.0020.001;rgn=main;vi ew=text;xc=1;g=mfsg, diakses pada 25 November 2016. Lihat juga Lynn D. Wardle, "Equality Principles as
} 
Salah satu wacana yang paling hangat dalam masa dua dekade terakhir mengenai hak asasi manusia adalah adanya konflik antara dua 'ideologi' yang berbeda dalam penerapan hak asasi manusia, yaitu universalitas dengan relativisme budaya. ${ }^{7}$ Pandangan universalitas hak asasi manusia melihat bahwa hak asasi manusia adalah berlaku secara universal, berlaku sama di semua tempat karena hak asasi manusia melekat pada harkat manusia itu sendiri dan bersumber dari teori hukum alam. Dalam perspektif umum, menurut kalangan relativis budaya, tidak ada suatu hak asasi manusia yang bersifat universal, dan teori hukum alam mengabaikan dasar masyarakat dari identitas individu sebagai manusia, karena seorang manusia selalu menjadi produk dari beberapa lingkungan sosial dan budaya. ${ }^{8}$

Tulisan ini mengkaji mengenai penerapan prinsip 'equal protection' yang merupakan prinsip penting dalam hukum hak asasi manusia dalam putusan Mahkamah Agung Amerika Serikat dalam kasus Obergefell et al. v. Hodges, Director, Ohio Department of Health. Putusan Mahkamah Agung Amerika Serikat yang mengesahkan perkawinan sesama jenis di Amerika Serikat ini dianggap monumental dan memiliki pengaruh yang cukup besar ke negara - negara lain, termasuk di Indonesia. ${ }^{9}$ Selain itu, tulisan ini bertujuan untuk melihat bagaimana perkawinan sesama jenis di Indonesia apabila ditinjau dari perspektif universalitas dan relativisme budaya dari hak asasi manusia. Berdasarkan latar belakang tersebut, maka Tulisan ini hendak menjawab dua permasalahan, yaitu: Bagaimana penerapan prinsip equality dalam pertimbangan putusan hakim Mahkamah Agung Amerika Serikat mengenai perkawinan sesama jenis dalam kasus Obergefell et al. v. Hodges, Director, Ohio Department of Health?; dan Bagaimanakah perkawinan sesama jenis dalam sistem hukum Indonesia apabila ditinjau dari perspektif universalitas - relativisme budaya dari hak asasi manusia? Permasalahan ini dikaji secara normatif dengan menggunakan pendekatan konseptual, pendekatan kasus dan pendekatan komparatif.

Asserted Justifications for Mandating the Legalization of Same-Sex Marriage in American and IntercountryComparative Constitutional Law", The BYU Journal of Public Law, 27 BYU J. Pub. L. 489, 2013.

${ }^{7}$ Knut D. Asplund, Suparman Marzuki, Eko Riyadi, ed., Hukum Hak Asasi Manusia (Yogyakarta: PUSHAM UII, 2008), hlm. 18.

${ }^{8}$ Satya Arinanto, Hak Asasi Manusia dalam Transisi Politik di Indonesia, (Jakarta: Pusat Studi Hukum Tata Negara Fakultas Hukum Universitas Indonesia, 2015), hlm. 91.

${ }^{9}$ Lih."Legalisasi pernikahan sejenis di AS 'kuatkan gerakan di Indonesia", 29 Juni 2015, http://www.bbc.com/indonesia/majalah/2015/06/150629 trensosial_lgbt, diakses pada 29 Mei 2017. Dalam situs berita tersebut dikatakan bahwa RR Sri Agustine, pejuang persamaan hak LGBT dari Ardhanary Institute mengatakan Amerika memiliki pengaruh yang cukup besar ke negara-negara lain di Eropa dan Asia. "(Ini) menjadi motivator. Semakin banyak negara-negara yang melegalkan pernikahan sesama jenis, akan semakin menguatkan gerakan-gerakan kita," katanya kepada BBC Indonesia. 


\section{Analisis dan Pembahasan}

\section{Prinsip Equality dan Hak Asasi Manusia}

Equality atau kesetaraan merupakan prinsip penting dalam hak asasi manusia, dokumen dokumen hak asasi manusia dilandasi oleh prinsip ini. ${ }^{10}$ Sedemikian pentingnya prinsi 'equality' sehingga digambarkan oleh Privy Council dalam Matadeen v Pointu' ${ }^{11}$ sebagai 'one of the building blocks of democracy'. ${ }^{12}$ Konsep hak asasi manusia ada berdasarkan prinsip kesetaraan / equality dari semua manusia. ${ }^{13}$ Dikatakan juga bahwa prinsip equality adalah diasosiasikan secara langsung dengan hak asasi manusia sebagai hak atas equality - bahkan sebenarnya, tanpa equality, maka hak asasi manusia tidak memiliki makna. ${ }^{14}$ Meski prinsip equality merupakan prinsip yang fundamental dan penting dalam perlindungan hak asasi manusia, namun prinsip tersebut bukanlah prinsip yang dapat diterapkan dengan mudah, bahkan sebenarnya bisa menjadi kompleks dalam penerapannya. Dan sebagaimana pendapat Christopher J. Peters, bahwa "if we treat people equally, we do not necessarily treat them rightly." 15 Dengan perkataan lain, equal treatment bukan merupakan semata - mata tujuan itu sendiri. Sedangkan mengenai keterkaitan antara prinsip equality dengan hak asasi manusia sebagaimana yang telah diuraikan di atas, Lucy Vikers memiliki pandangan yang berbeda: ${ }^{16}$ Menurutnya, tidak selamanya kedua hal ini (equality dan hak asasi manusia) bisa sejalan, bahkan bisa terjadi benturan antara keduanya.

Secara umum, pengertian equality dibedakan menjadi dua, yaitu: (i) pengertian secara formal yang dapat diartikan sebagai "equals should be treated equally"; dan (ii) substantive equality. Pengertian equality secara formal merupakan pendekatan yang umum dan tradisional yang digunakan dalam banyak sistem hukum nasional, dan memiliki keterkaitan dengan pandangan Aristoteles yang menyatakan bahwa "things alike should be treated alike" atau "treat like cases

10 Declaration of the Rights of Man and of Citizen tahun 1789 di Prancis diawali dengan Pasal 1 yang menyatakan: "Men are born and remain free and equal in rights." Begitu juga dengan Declaration of Independence di Amerika Serikat pada tahun 1776 yang menyatakan bahwa: "all men are created equal”. Terinspirasi oleh dokumen - dokumen HAM tersebut, Pembukaan Deklarasi Universal Hak Asasi Manusia (DUHAM) menyatakan: "Whereas recognition of the inherent dignity and of the equal and inalienable rights of all members of the human family is the foundation of freedom, justice and peace in the world,..." serta di dalam Pasal 1 yang menyatakan bahwa: "All human beings are born free and equal in dignity and rights. They are endowed with reason and conscience and should act towards one another in a spirit of brotherhood." Konvensi Internasional mengenai Hak - hak Sipil dan Politik / International Convention on Civil and Political Rights (ICCPR) juga mengakui prinsip kesetaraan dalam Konsideransnya.

${ }^{11}$ Matadeen and Others v M.G.C. Pointu and Others (1999) AC 98.

12 Anthony Hopkins, "Equality Before The Law: The Importance Of Understanding The Experience of 'Others' In The Criminal Justice System," (Disertasi Doctor of Philosophy in Law, University of Canberra, 2015), hlm. 17.

${ }^{13}$ J. Herman Burgers, "The Function of Human Rights as Individual and Collective Rights" dalam Jan Berting et.al, ed., Human Rights in a Pluralist World - Individual and Collectivities, The Hague: the Netherlands Commission for UNESCO, 1990, hlm. 65.

${ }^{14}$ Alda Facio dan Martha I. Morgan, "Equity or Equality for Women? Understanding CEDAW's Equality Principles", Alabama Law Review, 60 Ala. L. Rev. 1133, 2009.

${ }^{15}$ Christopher J. Peters, "Equality Revisited”, Harvard Law Review 110 Harv. L. Rev. 1210, April 1997.

${ }^{16}$ Lucy Vikers, "Equality and Human Rights: New Grounds for Concern”, http://sim.rebo.uu.nl/wpcontent/uploads/2015/04/Vickers_Equality-and-Human-Rights.pdf, diakses pada 3 Februari 2017. 
alike ${ }^{\text {"17 }}$. Hal inilah yang secara umum dipahami mengenai konsep equality. Pengertian equality secara formal dikenal juga dengan istilah "equality as consistency", "equality as rationality", atau "traditional prescriptive equality" 20 . Pendekatan formal ini menekankan bahwa karakteristik individual - baik fisik maupun karakteristik personal haruslah dianggap sebagai hal yang tidak relevan dalam menentukan apakah orang tersebut memiliki hak atas sesuatu. ${ }^{21}$ Pendekatan formal tidak menjamin bahwa hasil akhirnya merupakan equal outcome, bahkan hasil yang unequal / tidak sama merupakan sesuatu yang tidak terhindarkan apabila menggunakan pendekatan formal - karena natur dari pendekatan ini lebih ke prosedural dan bukannya remedial. ${ }^{22}$

Pengertian kedua, yaitu substantive equality bisa dibedakan lagi menjadi 'equality of result' dan 'equality of opportunity'. ${ }^{23}$ Pendekatan equality of result berupaya untuk menemukan hasil yang substantif dari suatu perlakuan tertentu. Sedangkan pendekatan equality of opportunity dimaksudkan untuk menyamakan hasil - selama hal tersebut merupakan konsekuensi dari hal - hal yang berada di luar kendali seseorang; namun di sisi lain juga mengizinkan dicapainya hasil yang berbeda selama hal tersebut merupakan konsekuensi dari pilihan yang bebas dari seseorang. ${ }^{24}$ Pendekatan ini berupaya untuk memberikan jalan tengah bagi dua pendekatan sebelumnya (formal equality dan equality of result). Equality of opportunity berupaya untuk menyamakan titik awal nya yang bisa dilakukan dengan cara memberikan perlakuan tertentu bagi pihak yang kurang beruntung, yaitu bisa dengan menyingkirkan penghalang yang ada, atau secara positif dengan memberikan langkah positif tertentu (affirmative action). ${ }^{25}$

Prinsip 'equality' juga sering dikaitkan dengan prinsip non diskriminasi - yaitu jika semua orang setara, maka seharusnya tidak ada perlakuan yang diskriminatif. ${ }^{26}$ Meski demikian, menurut

${ }^{17}$ Stefan Gosepath, "Equality”, https://plato.stanford.edu/entries/equality/, diakses pada 18 Maret 2017.

18 Jason Pobjoy "Treating Like Alike: The Principle of Nondiscrimination as a Tool to Mandate The Equal Treatment of Refugees and Beneficiaries of Complementary Protection", Melbourne University Law Review Volume 34, 2010, mengutip Fredman dalam "Combating Racism with Human Rights".

${ }^{19}$ Ibid., mengutip McCrudden dalam "Equality and Non - Discrimination".

${ }^{20}$ Christopher J. Peters mengistilahkan pengertian equality secara formal ini dengan "traditional prescriptive equality", yaitu yang menyatakan bahwa "identically situated people are entitled to be treated identically." Lih. Christopher J. Peters, "Equality Revisited”, loc.cit. Namun secara umum, istilah yang digunakan adalah: "formal equality".

${ }^{21}$ Ibid.

${ }^{22}$ Martha Albertson Fineman, "Equality Across Legal Cultures: The Role for International Human Rights", Thomas Jefferson Law Review, 27 T. Jefferson L. Rev. 1, Fall 2004.

${ }^{23}$ Ibid. Lihat juga Clifford, "Locating Equality", loc.cit.

${ }^{24}$ Gosepath, loc.cit.

${ }^{25}$ Pobjoy, loc.cit.

${ }^{26}$ Knut D. Asplund, Suparman Marzuki, Eko Riyadi, ed., op.cit.,hlm. 40. Dikatakan bahwa diskriminasi pada dasarnya merupakan kesenjangan perbedaan perlakuan dari perlakuan yang seharusnya sama/setara. Terdapat dua macam diskriminasi : (i) Diskriminasi langsung, yaitu ketika seseorang baik langsung maupun tidak langsung diperlakukan dengan berbeda (less favourable) daripada lainnya; dan (ii) Diskriminasi tidak langsung, yang muncul sebagai dampak dari hukum atau dalam praktek hukum merupakan bentuk diskriminasi, walaupun hal itu tidak ditujukan untuk tujuan diskriminasi. Misalnya, pembatasan pada hak kehamilan jelas akan berpengaruh lebih besar kepada perempuan daripada kepada laki-laki. 
Jason Pobjoy, prinsip equality dan non diskriminasi adalah konsep yang kompleks dan merupakan hal yang berbeda. ${ }^{27}$ Ia menjelaskan bahwa lawan dari equality adalah inequality, namun inequality tidaklah sama dengan diskriminasi. Pobjoy mengutip Vierdag yang menyatakan bahwa diskriminasi terjadi apabila suatu perlakuan yang sama ataupun suatu perlakuan yang tidak sama dihasilkan dari penilaian yang 'keliru' mengenai relevan atau tidaknya atribut manusia yang dijadikan pertimbangan.

\section{Perspektif Universalitas Relativisme Budaya dalam Konsep Hak Asasi Manusia}

Merupakan konsepsi yang diterima secara umum bahwa seseorang tidak melakukan apa pun untuk mendapatkan harkatnya, dan tidak ada yang dapat dilakukannya yang dapat membuatnya kehilangan harkatnya sebagai seorang manusia. ${ }^{28}$ Hal tersebut telah membuat para ahli menyimpulkan bahwa hak asasi manusia bersumber bukan dari hukum positif, melainkan dari hukum alam. ${ }^{29}$ Dan hukum alam tetap merupakan dasar filosofi yang paling meyakinkan mengenai konsep hak asasi manusia. ${ }^{30}$ Konsep hak asasi manusia dengan demikian dipahami sebagai hak individual yang universal dan yang melekat, sehingga (seharusnya) berlaku di mana saja dan kapan saja, tanpa bergantung pada sistem politik atau kebudayaan tertentu. ${ }^{31}$

Ide bahwa hak asasi manusia adalah universal dan menjadi norma bersama bagi Negara-negara dan kebudayaan merupakan sesuatu yang menarik dan memberi pesan yang kuat, dan juga merupakan sesuatu yang inklusif, di mana setiap orang meski berbeda-beda secara kebudayaan dan sejarah namun memiliki sesuatu yang sama, yaitu kemanusiaan mereka. ${ }^{32}$ Para pembela hak asasi manusia menyatakan bahwa hak-hak pokok adalah universal, melampaui batas -batas nasional maupun kultural yaitu bahwa setiap manusia berhak atas perlindungan dasar dan bahwa keberadaan hukum internasional adalah penting untuk memastikan perlindungan atas hak-hak tersebut. ${ }^{33}$ Meski hak asasi manusia adalah universal, namun sebagaimana menurut Jack Donnelly, "cultural relativity is an undeniable fact; moral rules and social institutions evidence an astonishing cultural and

\footnotetext{
${ }^{27}$ Pobjoy, loc.cit.

${ }^{28}$ Federico Lenzerini, The Culturization of Human Rights Law, (New York: Oxford University Press, 2014), hlm. 16.

${ }^{29}$ Carlos Santiago Nino, The Ethics of Human Rights, New York: Oxford University Press, 1991, hlm. 10.

${ }^{30}$ Federico Lenzerini, loc.cit.

${ }^{31}$ Olivier Roy dan Pasquale Annicchino, "Human Rights between Religions, Cultures, and Universality" dalam Ana Filipa Vrdoljak, ed., The Cultural Dimensions of Human Rights, (Oxford: Oxford University Press, 2013), hlm. 13.

${ }^{32}$ Kory Sorrell, "Cultural Pluralism and International Rights", Tulsa Journal Comparative and International Law, 10 Tulsa J. Comp. \& Int'l L. 369 Spring, 2003.

${ }^{33}$ Mark D. Kielsgard, "Critiquing Cultural Relativism: A Fresh View from the New Haven School of Jurisprudence”, Cumberland Law Review, 42 Cumb. L. Rev. 441, 2011 / 2012.
} 
historical variability." ${ }^{34}$ Lenzerini menyatakan hal yang serupa, yaitu adalah fakta bahwa masyarakat telah berkembang dalam model yang begitu heterogen, dengan skema sosial dan pola interaksi yang sangat dipengaruhi oleh kondisi lingkungan di mana mereka ada. ${ }^{35}$ Pandangan relativisme budaya menekankan pada keunikan tradisi, nilai - nilai dan pandangan hidup yang ada di berbagai masyarakat, dan menyimpulkan bahwa pandangan universalisme hak asasi manusia tidak mengakui dan tidak menghormati adanya variasi budaya tersebut. ${ }^{36}$ Hak asasi manusia juga jelas memiliki suatu sejarah dan asal usul yang terbentuk dan terdefinisikan dalam konteks budaya dan sejarah. ${ }^{37}$ Sehingga, teori mengenai hak asasi manusia dikatakan cenderung untuk berlaku di antara dua spektrum: Pertama, yang berdasarkan pada teori hukum alam; dan kedua, yang berlandaskan pada teori relativisme budaya pada ujung spektrum lainnya. ${ }^{38}$

Pada tahun 1993, dalam World Conference on Human Rights di Vienna, telah diadopsi Vienna Declaration and Programme of Action yang terlihat mendukung 'culturally sensitive universalism', yaitu universalitas yang mengakui adanya keragaman. Bagi sebagian orang, hal tersebut telah menuntaskan pergulatan mengenai universalisme dan relativisme budaya. Namun menurut Lenzerini, perdebatan mengenai hal ini (universalitas dan relativisme budaya) masih tetap terbuka, yaitu mengenai sejauh mana kekhasan / keunikan yang ada dapat mempengaruhi persepsi dan penegakan hak asasi manusia dalam permasalahan-permasalahan yang nyata dialami. ${ }^{39}$ Pada tahun 2009, Lord Hoffmann menyatakan bahwa dalam tingkatan abstrak, hak asasi manusia bisa merupakan sesuatu yang universal. Namun demikian, dalam tingkatan penerapannya, dalam permasalahan-permasalahan yang konkrit, penerapannya memerlukan berbagai tawar menawar, kompromi, pertimbangan-pertimbangan yang hanya dapat dilakukan dalam konteks masyarakat dan sistem hukumnya. ${ }^{40}$ Terkait putusan-putusan dari ECtHR, Robert Spano mengutip Lord Justice Laws yang menyatakan bahwa bisa ada berbagai jalan keluar yang tidak sama atas isu-isu hak asasi manusia di Negara yang berbeda-beda mengenai

\footnotetext{
${ }^{34}$ Jack Donnelly, "Cultural Relativism and Universal Human Rights”, Human Rights Quarterly Vol. 6, No. 4 (Nov., 1984), hlm. 400-419.

${ }^{35}$ Federico Lenzerini, The Culturalization of Human Rights Law, op.cit., hlm. 6.

${ }^{36}$ Richard Klein, "Cultural Relativism, Economic Development and International Human Rights in the Asian Context", Touro International Law Review, Spring, 2001

${ }^{37}$ Olivier Roy dan Pasquale Annichino, op.cit. Menurut Roy dan Annichino, sejarah dan asal - usul hak asasi manusia terutama terbentuk dalam konteks budaya dan sejarah di Inggris dan Amerika Serikat pada saat mulai Masa Pencerahan - juga dapat dirujuk pada masa yang lebih lampau, misalnya pada saat penulisan harbeas corpus.

${ }^{38}$ Satya Arinanto, Hak Asasi Manusia dalam Transisi Politik di Indonesia, op.cit., hlm. 91.

${ }^{39}$ Federico Lenzerini, op.cit. hlm. 12

${ }^{40}$ Robert Spano, "Universality or Diversity of Human Rights? Strasbourg in the Age of Subsidiarity", Human Rights Law Review, 2014, 14, hlm. 487-502.
} 
fakta-fakta yang serupa. ${ }^{41}$ Cyra Choudhury juga menyatakan bahwa hak - hak universal secara teori adalah 'universal', namun bagaimana hak-hak tersebut diberlakukan dalam prakteknya adalah melibatkan juga unsur budaya dan agama. ${ }^{42}$ Kesimpulan Jack Donnelly mengenai hak asasi manusia adalah bahwa hak asasi manusia merupakan relatively universal. Hak asasi manusia adalah universal, namun pada saat yang sama juga merupakan sesuatu yang relatif. ${ }^{43}$

Lenzerini menawarkan suatu metodologi untuk mengidentifikasi hal-hal apa yang merupakan ukuran dari universalitas hak asasi manusia, yaitu dengan memberikan beberapa rumusan mengenai universalitas dari hak asasi manusia: ${ }^{44}$

(i) 'Foundational universalism', yaitu merujuk pada pertanyaan mendasar mengenai apakah hak asasi manusia dapat dianggap sebagai 'universal' secara kultural, moral, sosial dan terutama secara legal. Bagian ini merujuk pada sesuatu yang absolut, dalam arti bahwa semua orang dan masyarakat - tanpa kecuali - memiliki hak asasi manusia.

(ii) 'Conceptual universalism', pada tahapan ini, hak asasi manusia adalah hampir universal. Komposisi dari hak - hak ini (sebagai suatu sistem atas hak - hak secara menyeluruh) adalah bisa berbeda dari satu wilayah dengan wilayah lainnya.

(iii) 'Structural universalism' yang merujuk pada struktur dan muatan yang spesifik dari setiap ukuran hak asasi manusia secara individual, di mana mayoritas dari hak - hak ini adalah 'culturally variable'. Ketika telah diasumsikan bahwa suatu standar hak asasi manusia adalah universal, tahapan selanjutnya adalah memastikan apakah isi dari hak tersebut adalah berlaku sama di seluruh dunia bagi setiap individu yang merupakan bagian dari kelompok masyarakat yang berbeda - beda? Tahapan ini merupakan aspek di mana penghargaan atas isu kulturalisasi dari hak asasi manusia adalah paling penting. Dikatakan bahwa: 'Since the expectation of human beings may be different from each other, human rights standards need to be flexible enough to allow that such different expectations may be satisfied in concrete terms." 45

\footnotetext{
${ }^{41}$ Robert Spano, loc.cit.

42 Cyra Akhila Choudhury, "Beyond Culture: Human Rights Universalisms versus Religious and Cultural Relativism in the Activism for Gender Justice", Berkeley Journal of Law, Gender and Justice, Volume 30, Issue 2, Article 2, 2015.

${ }^{43}$ Jack Donnelly, "Human Rights: Both Universal and Relative (A Reply to Michael Goodhart)", Human Rights Quarterly, Vol. 30, No. 1 (Feb., 2008), pp. 194-204, http://www.jstor.org/stable/20486703, diakses pada 1 Mei 2017.

${ }^{44}$ Federico Lenzerini, op.cit., hlm. 31 - 32 dan 236 - 243. Lenzerini mengakui bahwa metodologi ini tidaklah benar - benar baru. Ia merujuk pada Jack Donelly yang dalam tulisannya "Cultural Relativism and Universal Human Rights" telah menawarkan juga suatu tingkatan variasi yang hirarkis yaitu: relativisme budaya secara substantive; interpretasi dari hak - hak individual; dan mengenai bentuk dari suatu hak tertentu.

45 Ibid.
} 


\section{Penerapan Prinsip Equality Dalam Putusan Mahkamah Agung Amerika Serikat (Kasus Obergefell et al. v. Hodges, Director, Ohio Department Of Health)}

Putusan Obergefell et.al v. Hodges menyatakan bahwa "the right of same-sex couples to marry that is part of the liberty promised by the Fourteenth Amendment is derived, too, from that Amendment's guarantee of the equal protection of the laws." Putusan ini banyak merujuk pada kasus Loving v. Virginia ${ }^{46}$ yang juga menggunakan equal protection doctrine yang membatalkan larangan perkawinan antar rasial, yaitu bahwa ketentuan yang melarang perkawinan antar rasial merupakan unequal treatment terhadap pasangan yang berbeda ras. Analogi ini merupakan analogi yang keliru sebagaimana dinyatakan oleh Girgis, George dan Anderson, ${ }^{47}$ yaitu bahwa larangan perkawinan antar rasial adalah merupakan dengan siapa seseorang diperbolehkan untuk menikah, dan tidak menyentuh mengenai apa konsep dari perkawinan itu sendiri. Jenis kelamin - lah, dan bukannya ras, yang merupakan unsur yang relevan secara rasional mengenai apa itu perkawinan. ${ }^{48}$ Lynn D. Wardle juga berpendapat demikian, bahwa dari perspektif mengenai keabsahan perkawinan, ras bukanlah unsur atau pertimbangan yang relevan ${ }^{49}$. Wardle mengutip Colin Powell yang menyatakan bahwa: "Skin color is a benign non-behavioral characteristics. Sexual orientation is perhaps the most profound of human behavioral characteristics. Comparison of the two is a convenient but invalid argument. ${ }^{, 50}$ Kasus Loving v. Virginia adalah mengenai hak seseorang dari satu jenis kelamin tertentu untuk menikahi orang lain dari jenis kelamin yang berbeda - apapun ras (atau bisa jadi agama, suku, atau status sosial ekonominya). ${ }^{51}$ Dengan demikian, menyamakan kasus perkawinan sesama jenis dengan perkawinan antar rasial adalah tidak dapat dilakukan. William C. Duncan mencatat bahwa ada yurisprudensi yang telah menyatakan bahwa kasus Loving v. Virginia adalah kasus

\footnotetext{
${ }^{46} 388$ U.S. 1 Loving v. Virginia (No. 395), diputuskan pada tanggal 12 Juni 1967. Kasus mengenai dua penduduk Virginia, Amerika Serikat yaitu Mildred Jeter (seorang wanita kulit hitam) dan Richard Loving (pria kulit putih) yang menikah namun diputuskan bahwa hal tersebut melanggar peraturan di Virginia yang melarang perkawinan antar rasial. Kasus ini dibawa ke Supreme Court yang kemudian memenangkan Richard Loving.

${ }^{47}$ Sherif Girgis, Robert P. George dan Ryan T. Anderson, "What is Marriage?", Harvard Journal of Law and Public Policy Vol. 34 , hlm. 245 - 287, 2010.

${ }^{48}$ Ibid.

${ }^{49}$ Lynn D. Wardle, “A Critical Analysis of Constitutional Claims for Same-Sex Marriage”, 1996 BYU L. Rev. 1 (1996).

${ }^{50}$ Ibid.

${ }^{51}$ Robert John Araujo, “A Natural Law Approach to an Issue of the Day: A Critique of the (Equality) Justification for Same Sex Marriage”, St. John's University Journal of Civil Rights and Economic Development, 26 J. Civ. Rts. \& Econ. Dev. 565, Spring, 2012.
} 
mengenai diskriminasi rasial sehingga argumentasinya tidak dapat diterapkan untuk isu perkawinan sesama jenis. $^{52}$

Pasangan berbeda ras menghasilkan anak yang memiliki ras campuran (mixed-race children), namun pasangan sesama jenis tidak dapat menghasilkan anak dengan jenis kelamin campuran (mixed-gender children). ${ }^{53}$ Putusan juga banyak merujuk pada kasus Lawrence v. Texas ${ }^{54}$ yang merupakan kasus yang membatalkan peraturan di Negara bagian Texas yang melarang pasangan sesama jenis untuk melakukan relasi seksual. Padahal, sebagaimana dinyatakan oleh Chief Justice Roberts dalam pandangan berbedanya, kasus Lawrence v. Texas adalah mengenai larangan terhadap pemerintah untuk melakukan intrusi atas kehidupan privat dari warganya ${ }^{55}$, dan tidak berkaitan dengan tuntutan pemohon dalam kasus Obergefell ini yang menghendaki pengakuan Negara atas perkawinan sesama jenis, yang tentunya memiliki dimensi publik. Kasus Lawrence v. Texas pada dasarnya adalah merupakan right to be left alone, hal mana berlawanan dengan tuntutan legalisasi perkawinan sesama jenis yang menuntut agar Negara campur tangan dan mengakui hubungan dari pasangan sesama jenis.

Analisa mengenai penerapan prinsip equality dalam kasus legalisasi perkawinan sesama jenis secara umum, dan dalam kasus Obergefell et.al v. Hodges secara khusus harus diawali dengan pemahaman mengenai apa itu perkawinan, agar kemudian dapat menentukan unsur-unsur apa saja yang relevan di dalamnya. Setelah menentukan unsur unsur yang relevan dalam konsep perkawinan, maka dilanjutkan dengan menganalisa apakah pasangan sesama jenis adalah similarly situated dengan pasangan heteroseksual. Terakhir, apakah perlakuan yang equal dalam hal perkawinan merupakan tujuan itu sendiri.

1) Apakah unsur-unsur yang Relevan dalam Perkawinan?

Penerapan prinsip equality dalam suatu kasus atau isu tertentu mengharuskan adanya penetapan mengenai apa unsur - unsur yang relevan dalam isu tersebut agar

\footnotetext{
${ }^{52}$ Kasus yang dimaksud adalah Baker v. Nelson, 191 N.W.2d 185, 187 (Minn. 1971), Wiliam C. Duncan, "The Mere Allusion to Gender: Answering the Charge that Marriage is Sex Discrimination", Saint Louis University School of Law Saint Louis University Law Journal, 46 St. Louis L.J. 963, Fall, 2002.

${ }^{53}$ George W. Dent Jr, "The Defense of Traditional Marriage", Faculty Publications Paper 515. http://scholarlycommons.law.case.edu/faculty_publications/515, 1999, diakses pada 16 Februari 2017.

${ }^{54}$ Lawrence v. Texas, 539 U. S. 558, 575. Diputuskan pada 26 Juni 2003. Kasus ini dirujuk sebanyak 13 (tiga belas) kali dalam Putusan Obergefell, et.al. v. Hodges.

${ }_{55}$ Salah satu kutipan dalam Putusan pada kasus Lawrence v. Texas sebagaimana dikutip oleh Chief Justice Roberts dalam pandangan berbedanya adalah bahwa peraturan di Texas yang melarang aktifitas seksual oleh pasangan sesama jenis merupakan "... unwarranted government intrusions" that "touc[h] upon the most private human conduct, sexual behavior. . . in the most private of places, the home." Supreme Court of the United States, op.cit.
} 
prinsip equality dapat diterapkan dengan tepat. Menurut Girgis, George dan Anderson, sebelum dapat sampai pada kesimpulan apakah ketentuan mengenai perkawinan adalah melanggar Klausul Equal Protection atau tidak maka harus ditentukan terlebih dahulu apa itu Perkawinan dan mengapa sebenarnya Perkawinan harus disahkan oleh Negara. ${ }^{56}$

Sebagaimana yang diakui dalam Putusan Obergefell v. Hodges, "Marriage, in their view, is by its nature a gender-differentiated union of man and woman. This view has long been held - and continues to be held - in good faith by reasonable and sincere people here and throughout the world." Kalimat tersebut langsung dilanjutkan bahwa: "The petitioners acknowledge this history but contend that these cases cannot end there." (Penekanan dalam garis bawah oleh Penulis). Dari hal di atas jelas diakui bahwa telah sejak lama perkawinan secara alamiah diartikan sebagai persatuan pria dan wanita. Jenis kelamin yang berbeda dengan demikian merupakan unsur yang relevan dalam konsep perkawinan yang diterima secara umum sejak lampau. Unsur - unsur pembeda lain seperti warna kulit / ras, agama / kepercayaan, kebangsaan, tingkat ekonomi dan sosial, tingkat pendidikan, maupun usia $^{57}$ bukanlah merupakan unsur yang relevan dalam isu perkawinan. Kehendak para penggugat agar definisi perkawinan yang diterima sejak lama oleh 'people throughout the world' tidak berhenti pada kondisi saat ini ('these cases cannot end there') dapat menimbulkan permasalahan baru. Hal tersebut dapat membuka kemungkinan - kemungkinan gugatan lain di masa depan untuk terus memperluas konsep perkawinan entah sampai di mana batasnya. Menyebutkan beberapa dari berbagai kemungkinan gugatan yang dapat terjadi: perkawinan antara lebih dari dua orang (mengapa hanya dapat terdiri dari dua orang? Mengapa berhenti di situ dan tidak

\footnotetext{
${ }^{56}$ Sherif Girgis, Robert P. George dan Ryan T. Anderson, "What is Marriage?", op,cit. Sesuai maksud dari Penelitian ini maka pertanyaan kedua mengenai mengapa perkawinan harus disahkan oleh Negara tidak dielaborasi lebih lanjut. Namun secara singkat dapat dikatakan bahwa perkawinan memiliki dampak sosial dan sifatnya adalah diakui oleh publik, meski pada satu sisi merupakan sesuatu yang sakral / religius. Girgis, Goorge dan Anderson menyatakan bahwa: "Marriages, in contrast, are a matter of urgent public interest,as the record of almost every culture attests - worth legally recognizing and regulating." Dan mengutip George W. Dent Jr: "Despite some reckless claims that the liberal state must be value-neutral, thoughtful commentators recognize that goverment may promote certain values and discourage others. ... The expressive function is especially important in family law, which serves "both as a mechanism for meeting the needs of family members and as a vehicle for expressing our values and aspirations about family life to ourselves and our children." Thus the state may favour certain conduct,... but not in others, even though some people dislike the state's choices. The state may also discourage activities ... even if the state could not forbid these activities. As these examples suggest, govemment may promote (or discourage) conduct because it believes that the conduct benefis (or harms) the individual, even if the individual does not agree." Lih. George W. Dent Jr, loc.cit.

${ }^{57}$ Meski secara hukum terdapat pembatasan usia minimal untuk menikah karena alasan kesiapan biologis dan kesiapan mental. Apabila telah mencapai batas usia minimum, maka tidak ada larangan menikah dengan pasangan jenis kelamin lain berapapun perbedaan usianya.
} 
memperluasnya? $)^{58}$; perkawinan dengan satu orang tapi pada saat yang sama bisa dilakukan juga dengan satu orang lain dalam relasi perkawinan yang berbeda; dan seterusnya. Apabila gugatan demikian muncul, dan argumen equality digunakan tanpa batasan mengenai unsur-unsur yang relevan mengenai perkawinan karena 'these cases cannot end there' maka gugatan tersebut sangat mungkin diterima.

Chief Justice Roberts dalam pandangan berbedanya juga menyinggung mengenai hal ini ketika ia menyatakan bahwa alasan yang digunakan oleh Putusan mayoritas dapat diterapkan juga secara sama pada tuntutan akan perkawinan yang dilakukan oleh lebih dari 2 (dua) orang / plural marriage. Argumen - argumen dalam Putusan seperti: "[t]here is dignity in the bond between two men or two women who seek to marry and in their autonomy to make such profound choices," atau bahwa pasangan sesama jenis punya hak fundamental untuk menikah karena bila tidak, maka anak - anak yang orangtuanya merupakan pasangan sesama jenis akan "suffer the stigma of knowing their families are somehow lesser," dan sebagainya menurut Chief Justice Roberts adalah dapat juga diterapkan bagi tuntutan akan plural marriage. ${ }^{59}$ Dalam perdebatan lisan dengan pihak Pemohon, Pemohon berpendapat bahwa Negara tidak mengenal institusi demikian (plural marriage) - hal mana menurut Chief Justice Roberts: "But that is exactly the point: the States at issue here do not have an institution of same-sex marriage, either". 60

Penentuan unsur yang relevan dalam suatu konsep, dalam hal ini yaitu konsep perkawinan akan dapat membatasi klaim - klaim mengenai perlakuan setara / 'equal protection'. Apabila klaim yang diajukan adalah berada di luar unsur yang relevan dari suatu konsep tertentu maka klaim perlakuan yang setara / 'equal protection' semestinya tidak dapat dilakukan. Ralph Wedgwood sebagaimana dikutip oleh Matthew B. O’Brien menawarkan 3 (tiga) unsur dari perkawinan Barat modern, yaitu: (1) keintiman seksual; (2) kerjasama domestik dan ekonomi; (3) komitmen bersama secara sukarela untuk memelihara relasi tersebut. ${ }^{61}$ Tiga unsur perkawinan tersebut menjadi dasar untuk mengesahkan perkawinan sesama jenis dalam pandangan Wedgwood, hal mana

\footnotetext{
58 Sebagaimana yang dipertanyakan oleh Robert J. Araujo: "If that is indeed the case and there are three partners to any marriage, why not four? Why not five? Why not as many as can fit in the house or apartment?" Robert J. Araujo, loc.cit.

${ }^{59}$ Supreme Court of the United States, op.cit.

${ }^{60}$ Ibid.

${ }^{61}$ Mathew B. O’Brien, "Why Liberal Neutrality Prohibits Same-Sex Marriage: Rawls, Political Liberalism, and the Family", 1 Br. J. Am. Leg. Studies (2012), mengutip Ralph Wedgwood dalam The Fundamental Argument for Same Sex Marriage.
} 
menurut O'Brien adalah terlampau meluas karena apabila pandangan tersebut diterima maka relasi yang terjadi dalam prostitusi pun dapat dianggap sebagai perkawinan yang sah karena memenuhi ketiga unsur di atas. Karena itu dapat dikatakan bahwa unsur unsur yang relevan dalam perkawinan adalah (bahwa perkawinan merupakan relasi antara): (i) dua orang dewasa; (ii) jenis kelamin berbeda; (iii) bersifat eksklusif dan permanen. Dengan adanya penentuan unsur - unsur yang relevan dalam perkawinan, maka klaim - klaim mengenai legalisasi atas perkawinan berdasarkan prinsip equality / equal protection yang tidak memenuhi unsur - unsur sebagaimana tersebut di atas dengan demikian semestinya tidak dapat diterima.

2) Apakah Pasangan Sesama Jenis dan Pasangan Heteroseksual adalah sama secara relevan (relevantly alike / similarly situated)?

Pertanyaan ini menjadi dasar yang digunakan untuk menolak bahwa prinsip equality dapat diterapkan dalam legalisasi perkawinan sesama jenis. Putusan Obergefell v. Hodges menegaskan bahwa undang - undang perkawinan diberlakukan oleh para tergugat pada esensinya merupakan unequal - yaitu pasangan sesama jenis tidak mendapatkan keuntungan - keuntungan yang didapatkan oleh pasangan heteroseksual dan dihalangi dari penikmatan akan hak fundamentalnya. Putusan berargumen bahwa perkawinan memberikan akses yang sama kepada bagi pasangan homoseksual seperti kepada pasangan heteroseksual, dan bahwa ketidaksamaan (inequality) dalam akses pada perkawinan adalah salah. ${ }^{62}$ Selanjutnya dalam Putusan dinyatakan bahwa klausul Due Process dan klausul Equal Protection dalam Fourteenth Amendement melarang pelanggaran akan hak fundamental bagi pasangan sesama jenis untuk menikah. Mengenai hal ini dapat terdapat dua isu: (i) Subyek dari hak untuk menikah. Dari pertimbangan dalam Putusan di atas, maka yang menjadi subyek hak fundamental menurut Putusan adalah pasangan sesama jenis sebagai suatu kesatuan, bukannya individu. Padahal menurut William C. Duncan, yang menjadi korban dalam klaim-klaim konstitusional biasanya menuntut hak individu, bukan hak pasangan ${ }^{63}$. Jack Donnelly juga menekankan bahwa subyek dari hak asasi manusia adalah individu, bukan kelompok. ${ }^{64}$ Human Rights Committee dalam Komentar Umum mengenai ICCPR juga menyatakan bahwa "[t]the beneficiaries of the rights recognized by the Covenant are

\footnotetext{
${ }^{62}$ Lihat Nan D. Hunter, "Interpreting Liberty and Equality Through the Lens of Marriage", California Law Review Vol. 6, November 2015.

${ }^{63}$ Wiliam C. Duncan, loc.cit.

${ }^{64}$ Jack Donnelly, "Human Rights, Individual Rights and Collective Rights”, dalam Jan Berting et.al, ed., loc.cit., hlm. $39-62$.
} 
individuals" ${ }^{\prime 65}$; (ii) Membandingkan antara pasangan sesama jenis dengan pasangan heteroseksual: apakah sama secara relevan? Sekiranya bahwa sebagai pasangan dan bukannya individu sebagaimana dalam poin (i) di atas bisa mempunyai hak untuk menikah, maka pertanyaan lanjutannya adalah apakah pasangan sesama jenis adalah sama / relevantly alike / similarly situated dengan dengan pasangan heteroseksual sehingga sama - sama dapat memiliki hak untuk menikah? Makna dari prinsip equality menurut Araujo adalah dibatasi oleh beberapa batasan yang dapat dipahami baik secara rasional maupun secara faktual. ${ }^{66}$

Araujo menguraikan bahwa klaim equality bagi perkawinan sesama jenis tidak dapat didukung karena klaim tersebut mengabaikan dua pondasi yang esensi dari konsep equality, yaitu: (1) mengenai pentingnya fakta-fakta obyektif, dan (2) peran penting dari akal dan logika dalam menilai jangkauan kesamaan dan perbedaanperbedaan yang ada pada manusia. Ketika kedua hal ini (akal dan fakta obyektif) dikesampingkan maka hukum hanya menjadi alat oleh kelompok positivis murni, yaitu bahwa hukum adalah apapun yang dikatakan oleh pembuat hukum yang memberikan ijin untuk menyatakan 'equal' atas hal-hal yang menurut akal dan realitas obyektif adalah tidak equal. ${ }^{67}$ Relasi 'perkawinan' antara pria-wanita dengan pria-pria atau wanita-wanita dapat sama dalam hal-hal tertentu, namun tidak sama seluruhnya. Satu fakta yang tidak dapat dibantahkan adalah kemampuan prokreasinya hal mana mendapat banyak tentangan dari para pendukung perkawinan sesama jenis, yaitu bahwa dalam perkawinan pria-wanita pun tidak selalu akan terjadi prokreasi (baik karena mandul atau apabila terjadi perkawinan di usia lanjut). Namun, perkawinan pria-wanita ketika dilakukan maka selalu terdapat kemungkinan terjadinya prokreasi-hal mana tidak mungkin dapat terjadi (pada perkawinan sesama jenis). Dan kondisi tersebut bisa saja berubah, pasangan yang tadinya tidak dapat melahirkan anak, karena campur tangan medis bisa jadi mempunyai anak. ${ }^{68}$

\footnotetext{
${ }^{65}$ General Comment No. 31[80], "The Nature of the General Legal Obligation Imposed on States Parties to the Covenant" pada tanggal 26 Mei 2004 sebagaimana dikutip oleh Federico Lenzerini, "The Culturalization of Human Rights Law", op.cit., hlm. 147 - 148. Meski demikian, diutarakan juga dalam General Comment tersebut bahwa beberapa hak yang dilindungi dalam Konvensi (ICCPR) tersebut seperti kebebasan untuk mengekspresikan agama atau keyakinan (Pasal 18), kebebasan untuk membentuk asosiasi (pasal 22) dan kebebasan dari anggota kelompok minoritas (pasal 27) adalah dapat dinikmati bersama dengan yang lain dalam suatu komunitas.

${ }^{66}$ Araujo, loc.cit.

${ }^{67}$ Ibid.

${ }^{68}$ George W. Dent Jr, loc.cit.
} 
Dalam hal ini, pasangan sesama jenis dengan pasangan heteroseksual adalah tidak similarly situated. Araujo menguraikan bahwa meski relasi seksual antara pasangan sesama jenis dengan pasangan heteroseksual sama-sama dapat memberikan kenikmatan, namun dua macam relasi tersebut adalah berbeda secara substantif. Jenis relasi yang kedua memiliki kemampuan prokreatif yang merupakan fondasi dari eksistensi umat manusia secara realitas yang tidak terbantahkan, sedangkan jenis relasi yang pertama adalah steril sejak awalnya. ${ }^{69}$ Chief Justice Roberts dalam pendapat berbedanya menyatakan bahwa faktanya adalah manusia harus berprokreasi untuk dapat bertahan, dan prokreasi hanya dapat terjadi melalui relasi seksual antara seorang pria dan seorang wanita, hal mana tidak dapat dilakukan oleh pasangan sesama jenis.

Penerapan prinsip equality yang dalam Putusan yaitu dengan berangkat dari kesimpulan bahwa pasangan sesama jenis dan pasangan heteroseksual adalah 'alike' sehingga semestinya diperlakukan sama dalam hal hak untuk menikah merupakan penerapan formal equality ('things alike should be treated alike'). Namun sebagaimana diuraikan di atas bahwa sebenarnya pun keduanya tidaklah sama, tidak alike, tidak similarly situated sehingga penerapan prinsip equality secara formal pun sebenarnya tidak dapat diterapkan.

3) Apakah Perlakuan yang Equal dalam Perkawinan merupakan Tujuan itu Sendiri?

Sebagaimana telah disinggung dalam Bab 2 mengenai prinsip equality, apabila prinsip ini diterapkan secara formil dan bukannya secara substantif maka dapat menghasilkan putusan yang wrongly equal. Asumsi bahwa setiap perlakuan yang berbeda merupakan diskriminasi yang tidak adil merupakan asumsi yang keliru ${ }^{70}$. Menurut Girgis, George dan Anderson, apabila setiap perlakuan yang berbeda (dalam kasus perkawinan) merupakan diskriminasi yang tidak adil, maka legalisasi perkawinan harus dapat diberikan juga bagi jenis-jenis relasi lain yang didasari oleh cinta seperti relasi 'perkawinan' yang temporer, bersifat terbuka, poligini, poliandri, relasi incest, ataupun bahkan yang lebih absurd: bestial union. Hal tersebut dikarenakan seseorang bisa saja menemukan bahwa diri mereka memiliki hasrat seksual dan romantik dengan pasangan yang lebih dari satu (baik yang bersifat konkuren maupun serial), atau dengan

\footnotetext{
${ }^{69}$ Araujo, loc.cit.

${ }^{70}$ Sherif Girgis, Robert P. George dan Ryan T. Anderson, loc.cit.
} 
orang yang dekat secara hubungan darah, atau bahkan pasangan yang bukan manusia. ${ }^{71}$ Argumen yang diberikan dalam Putusan adalah bahwa "The imposition of this disability on gays and lesbians serves to disrespect and subordinate them. And the Equal Protection Clause, like the Due Process Clause, prohibits this unjustified infringement of the fundamental right to marry." ${ }^{, 72}$ Argumen yang sama dapat digunakan juga untuk melegalisasi bentuk-bentuk relasi lainya sebagaimana disebutkan di atas. Sebagaimana diuraikan oleh Araujo bahwa William Eskridge yang merupakan pendukung perkawinan sesama jenis bahkan mengakui apabila penerapan prinsip equality pada isu perkawinan (yaitu bahwa pasangan sesama jenis juga berhak diperlukan sama dengan pasangan heteroseksual untuk menikah) akan dapat menghasilkan ketidaksetaraan baru / new inequalities yaitu dengan cara merendahkan bentuk-bentuk relasi lain dan juga kehidupan orang lain yang tidak menghendaki relasi dengan komitmen jangka panjang. ${ }^{73}$ Matthew B. O'Brien juga mengkritik pandangan Frank Michelman yang berpendapat bahwa dalam politik liberal: "no political value can inhere in hostility or opposition to same-sex partnerships 'as such,' which can only reflect some religious or otherwise sectarian ethical doctrine." Dari hal tersebut maka menentang perkawinan sesama jenis akan merupakan suatu sikap yang sektarian, sehingga perkawinan sesama jenis semestinya harus disahkan. Menurut O'Brien hal tersebut adalah keliru, karena harus ada alasan yang masuk akal mengapa Negara harus memilih relasi homoseksual dibandingkan jenis-jenis relasi lain yang juga bersifat afektif, mengapa membatasi hanya pada pasangan sesama jenis. ${ }^{74}$ Memilih untuk memperluas hanya bagi kelompok yang dikehendakinya (pasangan sesama jenis) akan menjadi bentuk diskriminasi bagi jenis-jenis relasi lainnya yang juga bersifat intim. ${ }^{75}$ Karena itu, perlakuan yang sama / equal treatment terhadap pasangan sesama jenis dalam isu perkawinan tidak dapat menjadi semata-mata tujuan itu sendiri.

\section{Perkawinan Sesama Jenis dalam Perspektif Hukum Indonesia}

Merujuk metodologi yang diberikan oleh Lenzerini dalam menjembatani konsep universalitas dan relativisme budaya dari hak asasi manusia, maka secara 'foundational universalism', setiap manusia memiliki hak yang asasi semata - mata karena ia adalah manusia. Secara absolut, setiap manusia tanpa kecuali memiliki hak asasi di mana hak

\footnotetext{
${ }^{71}$ Ibid.

${ }^{72}$ Supreme Court of the United States, op.cit.

${ }^{73}$ Robert J. Araujo, loc.cit.

${ }^{74}$ Mathew B. O’Brien, loc.cit.

${ }^{75}$ Ibid.
} 
untuk menikah adalah salah satunya. Dalam tahapan berikutnya, yaitu conceptual universalism, hak asasi manusia menurut Lenzerini adalah hampir universal. Pada tingkatan berikut, yaitu structural universalism, pada bagian ini terjadi kulturalisasi dari hak asasi manusia yang bertujuan memberikan muatan yang konkrit dari standar hak asasi manusia yang abstrak. ${ }^{76}$ Hak untuk menikah sebagai hak asasi manusia diakui sebagai bagian dari hak asasi yang universal. Namun dalam pelaksanaan secara konkrit, terdapat kekhasan dan keunikan dalam pengaturan lebih lanjut, serta dalam penerapan hak tersebut. Dalam dokumen hak asasi manusia internasional, yaitu DUHAM dan ICCPR, hak untuk menikah merupakan hak yang disandingkan dengan hak untuk membentuk suatu keluarga, tanpa rujukan pada hak untuk melanjutkan keturunan dan tanpa rujukan pada ketentuan agama sebagai syarat sahnya suatu perkawinan.Sedangkan dalam aturan hukum di Indonesia, dua unsur terakhir (untuk melanjutkan keturunan dan rujukan pada agama sebagai landasan sah-nya perkawinan) merupakan bagian penting dari pengaturan mengenai hak untuk menikah. Indonesia, meski bukan merupakan Negara agama, namun Konstitusinya merupakan 'Godly Constitution' yang menurut Jimly Asshidique di antara negara-negara yang mempunyai Konstitusi tertulis, Konstitusi Indonesia merupakan Konstitusi yang memuat kata-kata 'Tuhan' dan 'Agama' paling banyak di dunia. ${ }^{77}$ Dari uraian mengenai penggunaan kata-kata tersebut dalam UUD 1945, menurut Asshidique sangatlah jelas bahwa UUD 1945 merupakan 'a very Godly Constitution', sangat berketuhanan sehingga tidak dapat ditafsirkan sebagai suatu 'Godless Constitution' yang dapat mengusung ide freedom from religion sebagai bentuk yang ekstrem dari 'freedom of religion'. ${ }^{78}$ Dalam Naskah Komprehensif Perubahan UUD 1945 dalam Buku II mengenai sendi-sendi/Fundamental Negara diuraikan mengenai prinsip dasar Negara Republik Indonesia pada masa sidang Badan Penyelidik Usaha Persiapan Kemerdekaan (BPUPK)

\footnotetext{
${ }^{76}$ Federico Lenzerini, loc.cit.

${ }^{77}$ Kata 'Allah' disebut 2 kali, 'Tuhan' 2 kali, kata 'Agama' disebut 10 kali, kata 'kepercayaan' 2 kali, kata 'keimanan' disebut 1 kali, kata 'ketakwaan' juga 1 kali, perkataan 'Yang Maha Esa' disebut 2 kali, dan perkataan 'Yang Maha Kuasa' 1 kali. Artinya, meskipun ketika disahkan pada tanggal 18 Agustus 1945, pernah terjadi pencoretan 7 kata dari naskah Pembukaan UUD 1945 yang berasal dari Piagam Jakarta 22 Juni 1945 , tetapi jumlah kata-kata yang mencerminkan ide tentang Tuhan dan agama tetap sangat banyak dan bahkan terbanyak di dunia. Kata 'Tuhan' yang digunakan dalam UUD 1945 menurut Asshidique adalah merujuk pada Tuhan dalam arti yang universal, bukan merujuk pada pengertian dari satu agama tertentu saja, tidak dapat ditafsirkan secara eksklusif. Jimly Asshidique, 'Tuhan' dan Agama dalam Konstitusi : Pergesekan antara Ide-Ide 'Godly Constitution Versus Godless Constitution' www.jimly.com/makalah/namafile/130/Tuhan_Dalam_Konstitusi.pdf, diakses pada 19 Mei 2017.

${ }^{78}$ Ibid. Dalam penelitian yang dilakukan oleh Asshidique, secara umum, negara - negara lain yang mempunyai naskah konstitusi yang tertulis tidaklah mencantumkan kata Tuhan atau kata lainnya yang menunjukkan adanya pengakuan akan sistem nilai atau kepercayaan atau kekuatan transenden di luar kesepakatan antar manusia dalam pembentukan Negara.
} 
sebagaimana dinyatakan oleh Moh. Yamin dalam pidatonya mengenai prinsip Peri Ketuhanan yang disampaikan pada tanggal 29 Mei 1945 sebagai berikut:

Bahwa bangsa Indonesia yang akan bernegara merdeka itu ialah bangsa yang berperadaban luhur dan peradabannya itu mempunyai Tuhan Yang Maha Esa. Oleh sebab itu, maka dengan sendirinya kita insyaf bahwa negara kesejahteraan Indonesia Merdeka itu akan berketuhanan. Tuhan akan melindungi negara Indonesia Merdeka itu. ${ }^{79}$ :

Dalam Naskah Komprehensif Perubahan UUD 1945 dalam Buku II mengenai sendisendi/Fundamental Negara di atas juga dinyatakan bahwa: "Cita-cita ketuhanan Yang Maha Esa sebagai sila yang pertama merupakan dasar yang kukuh untuk memberi ruang hidup kepada sifat religius bangsa Indonesia. Sila itu juga merupakan suatu jaminan akan adanya kebebasan beragama." Dari Naskah tersebut nampaklah bahwa Ketuhanan merupakan prinsip dasar yang enjiwai Konstitusi Negara Republik Indonesia. ${ }^{80}$ Sehingga di Indonesia, apabila hendak melihat bagaimana perkawinan sesama jenis dalam sistem hukum di Indonesia, maka harus merujuk pada ajaran agama-agama yang ada di Indonesia mengenai konsep perkawinan dan khususnya mengenai perkawinan sesama jenis. Agamaagama yang ada secara tegas membatasi bahwa perkawinan merupakan ikatan antara seorang pria dan seorang wanita.

Sampai saat Penelitian ini disusun, belum ada kasus yang menuntut pengesahan perkawinan sesama jenis di Indonesia. Beberapa berpendapat bahwa hal ini masih terlalu

\footnotetext{
${ }^{79}$ Tim Penyusun Revisi Naskah Komprehensif Perubahan Undang-Undang Dasar Republik Indonesia Tahun 1945, Latar Belakang, Proses, Dan Hasil Pembahasan 1999-2002, Naskah Komprehensif Perubahan UndangUndang Dasar Negara Republik Indonesia Tahun 1945 Latar Belakang, Proses, Dan Hasil Pembahasan 19992002 Buku II Sendi-Sendi / Fundamen Negara (Edisi Revisi), Jakarta: Sekretariat Jenderal dan Kepaniteraan Mahkamah Konstitusi, 2010. Soekarno dalam pidatonya pada tanggal 1 Juni 1945 juga mengemukakan gagasannya sebagai berikut: "Saudara-saudara, apakah prinsip ke-5? Saya telah mengemukakan empat prinsip: 1. Kebangsaan Indonesia 2. Internasionalisme, atau peri kemanusiaan 3. Mufakat atau demokrasi 4. Kesejahteraan sosial 5. Prinsip Indonesia Merdeka dengan bertakwa kepada Tuhan yang Maha Esa - Prinsip ketuhanan! Bukan saja bangsa Indonesia berTuhan, tetapi masing-masing orang Indonesia hendaknya berTuhan..."

${ }^{80}$ Indonesia bukan satu - satunya negara yang mendasarkan perkawinan pada nilai - nilai agama. Di Malaysia misalnya, terdapat dua Undang - undang yang mengatur perkawinan, yaitu bagi penganut agama Islam (Undang - undang Hukum Keluarga Islam Nomor 303 yang berlaku pada tahun 1987) dan Undang - undang Nomor 164 Tahun 1976 yang berlaku bagi mereka yang tidak beragama Islam. Undang - undang Hukum Keluarga Islam Nomor 303 tentunya memberlakukan ketentuan - ketentuan perkawinan dalam Islam, sedangkan Undang undang Nomor 164 Tahun 1976 juga mengacu pada ketentuan dalam agama masing - masing yang dianut oleh warga Malaysia yang melakukan pernikahan. Lihat Rita Reddy, "Marriage and Divorce Regulation and Recognition in Malaysia”, Family Law Quarterly, Vol. 29, No. 3 (Fall 1995), pp. 613-625. Begitu juga di Italia, di mana Gereja Katolik Roma adalah dominan dan memiliki pengaruh yang kuat, baik dalam keputusan keputusan politik maupun dalam beberapa aspek individu tertentu. Hubungan seksual pranikah, hidup bersama di luar relasi perkawinan, serta perceraian dilarang oleh Gereja di mana kehidupan pernikahan dan keluarga dipandang tinggi. Agama dan hal - hal yang berkaitan dengan keagamaan di Itali masih memiliki peran penting dalam berbagai aspek di Negara tersebut. Lih. Roberto Impicciatore dan Francesco C. Billari, "Secularization, Union Formation Practices, and Marital Stability: Evidence from Italy," European Journal of Population / Revue Européenne de Démographie, Vol. 28, No. 2 (May 2012), pp. 119-138.
} 
jauh dan belum akan dilakukan dalam waktu dekat. Yang ada adalah permohonan pengujian UU Nomor 1 Tahun 1974 tentang Perkawinan terhadap UUD 1945, yaitu mengenai konstitusionalitas Pasal mengenai syarat sah - nya perkawinan. Permohonan tersebut diajukan ke Mahkamah Konstitusi pada tahun 2015 (Putusan Mahkamah Konstitusi Nomor 68/PUU-XII/2014). Kedua adalah kasus gugatan perbuatan melawan hukum yang diajukan oleh penggugat terhadap pasangannya karena perkawinan yang telah berlangsung ternyata merupakan perkawinan sesama jenis. ${ }^{81}$ Kasus ini sampai ke tahap kasasi dan diputus oleh Mahkamah Agung pada tahun 2014 (Putusan Mahkamah Agung Nomor $1103 \mathrm{~K} / \mathrm{Pdt} / 2014)$. Meski kedua kasus tersebut bukan merupakan tuntutan legalisasi perkawinan sesama jenis, namun dari pertimbangan Hakim dan Putusan Hakim dapat dilihat bagaimana konsep perkawinan yang diterima dalam sistem hukum di Indonesia, yaitu bahwa konsep perkawinan bersumber pada nilai-nilai agama, dan bahwa perkawinan sesama jenis bukanlah merupakan perkawinan yang sah.

Dalam perdebatan mengenai legalisasi perkawinan sesama jenis para pendukung legalisasi perkawinan sesama jenis mengkritik argumentasi yang digunakan oleh kelompok penentang perkawinan sesama jenis yang menggunakan alasan agama sebagai dasar penolakannya. Menurut para pendukung perkawinan sesama jenis, penggunaan alasan agama untuk menentang perkawinan sesama jenis adalah tidak dapat diterima lagi karena agama atau kepercayaan yang ada di dunia ini adalah begitu beragam, dan bahkan harus diakui juga adanya hak untuk tidak beragama. Namun faktanya, variasi dalam pengimplementasian hak-hak asasi tertentu memang merujuk pada nilai-nilai agama, yang tidak dapat disangkal masih mempengaruhi sebagian besar aspek kehidupan manusia, terkhusus di Indonesia. Meskipun Indonesia bukan merupakan Negara agama, namun di sisi lain juga bukan Negara dengan Godless Constitution. Merujuk pada pengajaran agama-agama yang dianut di Indonesia sebagaimana diuraikan di atas, perkawinan sesama jenis merupakan konsep yang tidak dapat diterima.

Selain rujukan pada aturan agama sebagai 'konsekuensi' dari penerapan perspektif universalitas dan relativisme budaya pada perkawinan sesama jenis di Indonesia, apabila merujuk pada penerapan prinsip equality sebagaimana telah dibahas sebelumnya, maka legalisasi perkawinan sesama jenis juga tidak dapat dilakukan. Prinsip equality merupakan prinsip dasar dalam konsep hak asasi manusia, yang diakui dan diterima secara meluas dalam dokumen-dokumen hukum hak asasi internasional. Prinsip equality ini juga

\footnotetext{
${ }^{81}$ Tiurma M.P. Allagan, “Are You “(Wo)Man” Enough to Get Married?”, Indonesia Law Review (2016) 3 : 345 -368 .
} 
menjiwai dan diatur dalam UUD 1945, yaitu dalam Pasal $27^{82}$ dan Pasal $28 D^{83}$, dan dalam UU Nomor 39 Tahun 1999 tentang Hak Asasi Manusia, yaitu dalam Pasal $3^{84}$, Pasal $4^{85}$, Pasal $5^{86}$, Pasal $38(3)^{87}$. Namun penerapan prinsip equality, yaitu 'equal treatment' atau perlakuan yang sama / setara tidak dapat serta merta diberlakukan pada semua isu tanpa melakukan analisa mengenai unsur - unsur yang relevan dari isu tersebut. Dalam konteks penelitian ini maka, isu yang dimaksud adalah mengenai perkawinan, yang diterima secara meluas sebagai persatuan pria dan wanita.

\section{Penutup}

Penerapan prinsip equality dalam Putusan Mahkamah Agung Amerika Serikat dalam kasus James Obergefell, et.al v. Hodges, Director, Ohio Department of Health menurut Penulis adalah tidak tepat. Penerapan prinsip equality dalam Putusan tersebut: (i) mengabaikan unsur-unsur yang relevan dalam konsep perkawinan; (ii) menyamakan antara pasangan sesama jenis dengan pasangan heteroseksual, padahal antara keduanya tidaklah berada pada situasi yang serupa/similary situated dan tidak sama secara relevan / relevantly alike; (iii) menjadikan perlakuan yang sama/equal treatment semata-mata sebagai tujuan itu sendiri dalam perkawinan sesama jenis, padahal perlakuan yang tidak sama (unequal treatment) tidak serta merta berarti telah terjadi diskriminasi. Dengan demikian, penggunaan prinsip equality untuk menuntut legalisasi perkawinan sesama jenis semestinya tidak dapat dilakukan.

Secara foundational universalism, hak asasi manusia merupakan sesuatu yang dimiliki secara asasi oleh setiap manusia. Namun pada sisi lain penerapan hak asasi manusia juga

\footnotetext{
82 Pasal 27 UUD 1945: “(1) Segala warga negara bersamaan kedudukannya di dalam hukum dan pemerintahan dan wajib menjunjung hukum dan pemerintahan itu dengan tidak ada kecualinya. .."

83 Pasal 28D UUD 1945: "(1) Setiap orang berhak atas pengakuan, jaminan, perlindungan, dan kepastian hukum yang adil serta perlakuan yang sama dihadapan hukum..."

${ }^{84}$ Pasal 3 UU Nomor 39 Tahun 1999: "(1) Setiap orang dilahirkan bebas dengan harkat dan martabat manusia yang sama dan sederajat serta dikaruniai akal dan hati nurani untuk hidup bermasyarakat, berbangsa, dan bernegara dalam semangat persaudaraan. (2) Setiap orang berhak atas pengakuan, jaminan, perlindungan dan perlakuan hukum yang adil serta mendapat kepastian hukum dan perlakuan yang sama di depan hukum. (3) Setiap orang berhak atas perlindungan hak asasi manusia dan kebebasan dasar manusia, tanpa diskriminasi."

${ }^{85}$ Pasal 4 UU Nomor 39 Tahun 1999: "Hak untuk hidup, hak untuk tidak disiksa, hak kebebasan pribadi, pikiran dan hati nurani, hak beragama, hak untuk tidak diperbudak, hak untuk diakui sebagai pribadi dan persamaan di hadapan hukum, dan hak untuk tidak dituntut atas dasar hukum yang berlaku surut adalah hak asasi manusia yang tidak dapat dikurangi dalam keadaan apapun dan oleh siapapun.”

${ }^{86}$ Pasal 5 UU Nomor 39 Tahun 1999: “(1) Setiap orang diakui sebagai manusia pribadi yang berhak menuntut dan memperoleh perlakuan serta perlindungan yang sama sesuai dengan martabat kemanusiaannya di depan hukum. (2) Setiap orang berhak mendapat bantuan dan perlindungan yang adil dari pengadilan yang objektif dan tidak berpihak. (3) Setiap orang yang termasuk kelompok masyarakat yang rentan berhak memperoleh perlakuan dan perlindungan lebih berkenaan dengan kekhususannya."

${ }^{87}$ Pasal 38 (3) UU Nomor 39 Tahun 1999: "Setiap orang, baik pria maupun wanita yang melakukan pekerjaan yang sama, sebanding, setara atau serupa, berhak atas upah serta syarat-syarat perjanjian kerja yang sama."
} 
memberikan perhatian terhadap adanya keberagaman budaya dan pada kekhasan budaya dari setiap komunitas masyarakat yang beragam, dalam batasan yang diperbolehkan oleh konsep universalitas dari hak asasi manusia (structural universalism). Hak untuk menikah adalah universal, namun secara structural universalism, terdapat variasi dalam pelaksanaannya menurut keberagaman dan kekhasan budaya yang ada dari setiap komunitas masyarakat. Dari perspektif ini, sebagaimana termuat dalam tataran aturan hukum yang berlaku di Indonesia maupun dalam putusan pengadilan yang ada yang berkaitan dengan perkawinan, maka perkawinan memiliki landasan pada nilai-nilai agama. Sedangkan menurut agama-agama yang dianut di Indonesia, hak untuk menikah tidaklah mencakup perkawinan sesama jenis adalah bertentangan dengan ajaran agama. Berdasarkan hal tersebut, dapat disimpulkan bahwa di Indonesia, hak untuk menikah tidaklah mencakup perkawinan sesama jenis.

Dengan demikian, baik dari perspektif universalitas relativisme budaya dari hak asasi manusia maupun dari penerapan prinsip equality (yang bukan bersumber pada nilai-nilai agama), maka perkawinan sesama jenis di Indonesia tidak dapat dilegalisasi. 


\section{Daftar Pustaka}

\section{Buku:}

Arinanto. Satya. (2015) Hak Asasi Manusia dalam Transisi Politik di Indonesia. Jakarta: Pusat Studi Hukum Tata Negara Fakultas Hukum Universitas Indonesia.

Asplund, Knut D. Suparman Marzuki, Eko Riyadi, ed. (2008). Hukum Hak Asasi Manusia Yogyakarta: PUSHAM UII.

Berting, Jan et.al, ed. (1990). Human Rights in a Pluralist World - Individual and Collectivities. The Hague: the Netherlands Commission for UNESCO.

Ishay, Micheline R. (2008). The History of Human Rights From Ancient Times to the Globalization Era, Berkeley: University of California Press.

Lenzerini, Federico. (2014). The Culturization of Human Rights Law. New York: Oxford University Press.

Nino, Carlos Santiago. (1991). The Ethics of Human Rights. New York: Oxford University Press.

Vrdoljak, Ana Filipa ed. (2013). The Cultural Dimensions of Human Rights. Oxford: Oxford University Press.

\section{Jurnal Dan Disertasi}

Allagan, Tiurma M.P. (2016). “Are You “(Wo)Man” Enough to Get Married?”. Indonesia Law Review 3 : $345-368$.

Araujo, Robert John. (2012). "A Natural Law Approach to an Issue of the Day: A Critique of the (Equality) Justification for Same Sex Marriage". St. John's University Journal of Civil Rights and Economic Development, 26 J. Civ. Rts. \& Econ. Dev. 565, Spring.

Choudhury, Cyra Akhila. (2015). "Beyond Culture: Human Rights Universalisms versus Religious and Cultural Relativism in the Activism for Gender Justice". Berkeley Journal of Law, Gender and Justice, Volume 30, Issue 2, Article 2.

Clifford, Jarlath. (2008). "Locating Equality: from Historical Philosophical Thought to Modern Legal Norms". The Equal Rights Review, Vol. One.

Donnelly, Jack. (1984) "Cultural Relativism and Universal Human Rights". Human Rights Quarterly Vol. 6, No. 4 November.

Duncan, Wiliam C. (2002) "The Mere Allusion to Gender: Answering the Charge that Marriage is Sex Discrimination". Saint Louis University School of Law Saint Louis University Law Journal, 46 St. Louis L.J. 963, Fall.

Facio, Alda dan Martha I. Morgan. (2009) "Equity or Equality for Women? Understanding CEDAW's Equality Principles". Alabama Law Review, 60 Ala. L. Rev. 1133. 
Fineman, Martha Albertson. (2004) "Equality Across Legal Cultures: The Role for International Human Rights". Thomas Jefferson Law Review, 27 T. Jefferson L. Rev. 1, Fall.

Girgis, Sherif, Robert P. George dan Ryan T. Anderson. (2010) "What is Marriage?". Harvard Journal of Law and Public Policy Vol. 34 , hlm. 245 - 287.

Hopkins, Anthony. "Equality before the Law: The Importance of Understanding the Experience of 'Others' in the Criminal Justice System." (Disertasi Doctor of Philosophy in Law, University of Canberra, 2015).

Hunter, Nan D. (2015) "Interpreting Liberty and Equality Through the Lens of Marriage", California Law Review Vol. 6, November.

Impicciatore, Roberto dan Francesco C. Billari. "Secularization, Union Formation Practices, and Marital Stability: Evidence from Italy". European Journal of Population / Revue Européenne de Démographie, Vol. 28, No. 2 (May 2012), pp. 119-138.

Kielsgard, Mark D. (2012). "Critiquing Cultural Relativism: A Fresh View from the New Haven School of Jurisprudence”. Cumberland Law Review, 42 Cumb. L. Rev. 441.

Klein, Richard. (2001) "Cultural Relativism, Economic Development and International Human Rights in the Asian Context”. Touro International Law Review, Spring.

O’Brien, Mathew B. (2012). "Why Liberal Neutrality Prohibits Same-Sex Marriage: Rawls, Political Liberalism, and the Family". 1 Br. J. Am. Leg. Studies.

Peters, Christopher J..(1997). "Equality Revisited". Harvard Law Review 110 Harv. L. Rev. 1210, April.

Pobjoy, Jason. (2010). “Treating Like Alike: The Principle of Nondiscrimination as a Tool to Mandate The Equal Treatment of Refugees and Beneficiaries of Complementary Protection". Melbourne University Law Review Volume 34.

Reddy, Rita."Marriage and Divorce Regulation and Recognition in Malaysia". Family Law Quarterly, Vol. 29, No. 3 (Fall 1995), pp. 613-625.

Sorrell, Kory. (2003) "Cultural Pluralism and International Rights". Tulsa Journal Comparative and International Law, 10 Tulsa J. Comp. \& Int'l L. 369 Spring.

Spano, Robert. "Universality or Diversity of Human Rights? Strasbourg in the Age of Subsidiarity". Human Rights Law Review, 2014, 14, hlm. 487-502.

Wardle, Lynn D. (2013). "Equality Principles as Asserted Justifications for Mandating the Legalization of Same-Sex Marriage in American and Intercountry-Comparative Constitutional Law". The BYU Journal of Public Law, 27 BYU J. Pub. L. 489. . (1996). "A Critical Analysis of Constitutional Claims for Same-Sex Marriage". 1996 BYU L. Rev. 1 . 


\section{Internet dan Lain - Lain}

Crehan, Margaret Gram dan Katherine Rickenbacker, "The Changing Debate on Same-Sex Marriage in the United States", Fall 2006-Spring 2007, http://quod.lib.umich.edu/cgi/t/text/textidx?cc=mfsfront;c=mfs;c=mfsfront;idno=ark55 83.0020.001;rgn=main;view=text;xc=1;g=mfsg, diakses pada 25 November 2016.

http://thelawdictionary.org/legalization/, diakses pada 29 Mei 2017.

"The State of Gay Rights Around The World", updated 14 Juni 2016, https://www.washingtonpost.com/graphics/world/gay-rights/, diakses pada $19 \mathrm{Mei}$ 2017.

Supreme Court of the United States, Obergefell et al. v. Hodges, Director, Ohio Department of Health, et.al, No. 14-556, 14-562, 14-571, 14-574, diputuskan pada 26 Juni 2015. Putusan diunduh dari https://www.supremecourt.gov/opinions/14pdf/14556_3204.pdf, diakses pada 10 April 2016.

https://www.law.cornell.edu/wex/fourteenth_amendment_0, diakses pada 27 Mei 2017.

"Legalisasi pernikahan sejenis di AS 'kuatkan gerakan di Indonesia", 29 Juni 2015, http://www.bbc.com/indonesia/majalah/2015/06/150629_trensosial_lgbt, diakses pada 29 Mei 2017.

Vikers, Lucy. "Equality and Human Rights: New Grounds for Concern". http://sim.rebo.uu.nl/wp-content/uploads/2015/04/Vickers_Equality-and-HumanRights.pdf, diakses pada 3 Februari 2017.

Donnelly, Jack. "Human Rights: Both Universal and Relative (A Reply to Michael Goodhart)“, Human Rights Quarterly, Vol. 30, No. 1 (Feb., 2008), pp. 194-204, http://www.jstor.org/stable/20486703, diakses pada 1 Mei 2017.

Gosepath, Stefan. "Equality", https://plato.stanford.edu/entries/equality/, diakses pada 18 Maret 2017.

Dent Jr, George W. “The Defense of Traditional Marriage”, Faculty Publications Paper 515. http://scholarlycommons.law.case.edu/faculty_publications/515, 1999, diakses pada 16 Februari 2017.

Asshidique, Jimly. “'Tuhan' dan Agama dalam Konstitusi : Pergesekan antara Ide-Ide 'Godly Constitution Versus Godless Constitution”, www.jimly.com/makalah/namafile/130/Tuhan_Dalam_Konstitusi.pdf, diakses pada 19 Mei 2017.

Tim Penyusun Revisi Naskah Komprehensif Perubahan Undang-Undang Dasar Republik Indonesia Tahun 1945. Latar Belakang, Proses, dan Hasil Pembahasan 1999-2002, Naskah Komprehensif Perubahan Undang-Undang Dasar Negara Republik Indonesia Tahun 1945 Latar Belakang, Proses, Dan Hasil Pembahasan 1999-2002 Buku II Sendi-Sendi / Fundamen Negara (Edisi Revisi). Jakarta: Sekretariat Jenderal dan Kepaniteraan Mahkamah Konstitusi, 2010. 